\title{
ЕС И КИТАЙ: ТОРГОВЛЯ ИЛИ СТРАТЕГИЯ
}

\begin{abstract}
Аннотация: В 2018 г. ЕС и Китай отметили 15-летие провозглашения всеобъемлющего стратегического партнёрства. В 2003 г., когда было принято решение о повышении уровня отношений, они не претендовали на глобальную роль. Китай проводил политику отказа от вступления в какие-либо союзы и не поднимал вопроса о своей ведущей роли в мире. ЕС довольствовался ролью экономического гиганта и всерьёз не обсуждал вопрос о создании собственных вооружённых сил. Если в начале XXI века руководители ЕС пытались, и часто успешно, обучать китайцев торговле в условиях открытого рынка, сегодня это диалог двух равных партнёров, причём Пекин превосходит Брюссель в выдвижении альтернативных моделей развития мира. Сегодня по объёмам торговли ЕС и Китай занимают, соответственно, первое и второе место в мире, а объём торговли между ними уступает лишь объёму торговли между ЕС и США. Сегодня в Европе всё чаще говорят о “европейской армии”, а китайцы думают о “Великой китайской мечте”. Предлагаемая статья не даёт однозначного ответа на вопрос о реальности этих планов, но обозначить рамки процессов их реализации.
\end{abstract}

Ключевые слова: ЕС, Китай, торговля, инвестиции, безопасность.

В ситуации, когда политика президента Трампа внесла неопределённость в отношения между тремя крупнейшими в мире экономическими партнёрами - США, Китаем и ЕС, отношения между Брюсселем и Пекином остаются одним из важнейших факторов мировой политики. Сегодня по опросам общественного мнения, проведённых в 2014 г., 60\% европейцев уверены, что Китай “уже заменил” или “вскоре заменит США” в качестве глобальной сверхдержавы, 49\% опрошенных назвали Китай “ведущей экономической державой”, тогда как лишь 37\% считают такой страной США [Pew, 2018]. В Брюсселе всё чаще высказывают недовольство тем, что политическая роль ЕС, очевидно, не соответствует экономической мощи союза, а президент Франции всё активнее ставит вопрос о независимых от НАТО европейских вооружённых силах. В условиях, когда президент США Дональд Трамп поставил под сомнение существование трансатлантических отношений и начал экономическую борьбу с ЕС и Китаем, стратегическое партнёрства между Брюсселем и Пекином в будущем может стать серьёзным фактором мировой политики. Однако в обозримом будущем шансы на подобный поворот в расстановке глобального миропорядка пока не слишком велики. Произойти это может только в том случае, если

(c) Носов Михаил Григорьевич - член-корр. РАН, член дирекции Института Европы РАН. Adpec: 125009, Россия, Москва, ул. Моховая, 11-3. E-mail: mikhailnosov@mail.ru

DOI: http://dx.doi.org/10.15211/soveurope620180517 
США продолжат политику разрушения экономических связей с Европой и Китаем, а ЕС превратится в самостоятельную военную силу.

Сегодня Китай стал одним из крупнейших торговых партнёров ЕС и страной, с которой Брюссель поддерживает активные политические связи. С 1998 по 2018 г. было проведено 20 саммитов, свыше 50 регулярных секторальных встреч, учредил два форума - диалог по проблемам экономики и торговли и диалог по вопросам стратегических отношениям с участием высших должностных лиц обеих сторон. Как заявил в 2016 г. председатель Европейской комиссии Хосе-Мануэль Баррозо "развитие стратегических, взаимовыгодных отношений с Китаем является одним из важнейших приоритетов внешней политики ЕС в этом веке" [Mahler, 2016].

\section{Стратегия отношений}

В совместном заявлении 20-го саммита ЕС - Китай в июле 2018 г. из 45 пунктов проблемам соблюдения прав человека был посвящён лишь один, два - вопросам безопасности, 18 - проблемам торговли и инвестициям, 16 - вопросам двустороннего сотрудничества, восемь - состоянию двусторонних отношений и международным проблемам ${ }^{1}$. Документ достаточно точно отражает состояние и характер отношений между ЕС и Китаем, в которых превалируют экономические связи.

Тем не менее ЕС и Китай ежегодно проводят встречи по обсуждению прав человека, на которых европейская сторона детально и подробно предоставляет список нарушений, но лишь иногда добивается успеха в своих попытках смягчить меры, предпринятые китайскими властями против, тех, кого китайское правительство считает нарушителями закона ${ }^{2}$. По оценке ЕC, никаких серьёзных позитивных сдвигов в вопросах соблюдения прав человека в Китае не происходит ${ }^{3}$. ЕС ведёт с Китаем диалог по вопросам предотвращения наркотрафика, международной преступности, кибер-преступности.

Хотя форум по вопросам безопасности в декабре 2017 г. призвал "к расширению сотрудничества по проблемам безопасности на Корейском полуострове, в Африке, на Ближнем и Среднем Востоке в Сирии и Афганистане, по вопросам ядерной сделки с Ираном, поскольку многосторонние действия в сфере безопасности требуют сотрудничества с Китаем, как с членом Совета Безопасности ООН", следнего времени география ограничивала их заинтересованность во взаимной безопасности. “Стратегическое партнёрство” ЕС и Китая носило ограниченный характер, за исключением начатой в 2008 г. операции “Аталанта" (EU NAVFOR Atalanta) BMC EC у берегов Сомали против пиратов, в ходе которой ВМС ЕС и КНР координировали свои действия.

\footnotetext{
${ }^{1}$ Joint statement of the $20^{\text {th }}$ EU-China Summit (concillium.europa.eu 16/07/2018).

${ }^{2}$ В пресс-релизе ежегодного диалога по правам человека в 2018 г., например, констатировалось что “в этом году диалог проходит в третью годовщину ареста 300 юристов, выступавших за соблюдение прав человека и защитников этих прав". (The EU and China annual Human Rights Dialogue (European External Action Service, Beijing, 12/12/2017).

${ }^{3}$ Как было отмечено в 2018 г. в документе Европарламента "в Китае мы видим ухудшение ситуации с правами человека и свободами, равно как и свойственную ему коррупцию". [Saarela, 2018: 22].

${ }^{4}$ Experts analyze future of EU-China peace and security cooperation at Beijing forum (European External Action Service, Beijing, 12/12/2017).
}

Современная Европа, 2018, №6 
Руководство ЕС до сих пор так и не отменило, введённое в 1989 г. эмбарго на продажу оружия в Китай. Пекин ежегодно, хотя и без особого нажима, призывает руководство ЕС “преодолеть идеологические барьеры и проводить более практическую политику" [Global Times, 2017], а в Европе противниками сохранения эмбарго остаются Франция и Германия

В 2016 г. произошло столкновение стратегических интересов между Китаем и ЕС. В 2016 г. правительство Франции вспомнило, что страна обладает эксклюзивной экономической зоной (EEZ) площадью в 11 млн кв. км, 62\% которой находится в Тихом океане, а $24 \%$ - в Индийском океане. Франция в июне 2016 г. в ходе встречи "Диалога Шангри Ла", предложила возглавить операцию "Свобода судоходства" (Freedom of Navigation Operation FONOP) в Южно-Китайском море под эгидой ЕC [The Diplomat, 2016].

В день открытия в Пекине 18-го саммита ЕС - КНР в июле 2016 г. состоялось решение Постоянного арбитражного суда в Гааге, который в конфликте между Филиппинами и Китаем принял сторону Манилы. Это дало повод председателю Европейской Комиссии Дональду Туску осторожно напомнить китайской стороне, что "поведение, основанное на международных правилах, в общих интересах, и Китай и ЕС должны придерживаться их”. Было принято решение в 2017 г. начать морское патрулирование в Южно-Китайском море. В патрулировании в Южно-Китайском море, кроме французских кораблей, участвовали ВМС США, Великобритании и ряда других стран.

\section{Торговля - основа отночений}

В отличие от США европейцы свой “поворот к Азии” обосновывали не политическими или военно-стратегическими соображениями ${ }^{2}$, а динамичным развитием экономики стран этого региона. В 2017 г. среди крупнейших торговых партнёров ЕС в Азии, на которую пришлось $20 \%$ импорта ЕС и $13,7 \%$ экспорта EC, на Китай пришлось $8,1 \%$ импорта и $3,3 \%$ экспорта, на Японию - $1,2 \%$ импорта и $1,1 \%$ экспорта, на страны АСЕАН - 3,1\% импорта и 1,7\% на Совет сотрудничества стран Залива $0,8 \%$ импорта и $1,9 \%$ экспорта $^{3}$. Брюссель и Пекин являются столицами двух крупнейших

${ }^{1}$ Франция вместе с Великобританией и Германией участвует в “Диалоге Шангри Ла”, который с 2001 г. ежегодно собирает военных министров Тихоокеанских стран, включая Россию и США для обсуждения проблем безопасности региона.

${ }^{2}$ В сентябре 2016 г., незадолго до президентских выборов в США, президент Барак Обама, позиционировавший себя “первым Тихоокеанским президентом”, выступил с речью, определившей политику США как “поворот к Азии”. В феврале 2016 г. на церемонии подписания соглашения о Транс-Тихоокеанском партнёрстве (ТТР) в Новой Зеландии Обама, говоря о политических целях договора, сказал, что “теперь они позволят Америке, а не таким странам как Китай, определять правила движения в XXI веке”. [Bradley, 2016] . Одним из первых решений президента Трампа был выход из ТТР и последующий за этим торговый конфликт с Китаем.

${ }^{3}$ Расчёт произведён с учётом внутрисоюзной торговли ЕС, которая значительно превосходит данные, её не учитывающие. В 2017 г. объём импорта ЕС с учётом внутрисоюзной торговли составил 4993,2 млрд евро, без её учёта - 1859,7 млрд, соответственно экспорт составил 5062,1 и 1878,6 млрд евро. В торговле ЕС в 2017 г. без учёта внутрисоюзной торговли на страны Азии пришлось свыше $30 \%$, в том числе на Китай - 20,2\% импорта и Современная Европа, 2018, №6 
мировых торговых центров. На ЕС и Китай в 2017 г. пришлось 43,7\% мировой торговли. ЕС является крупнейшим в мире экспортёром (32,5\% мирового экспорта) и импортёром (31,6\% мирового импорта). Китай занимает второе место после ЕС по экспорту $(12,9 \%)$ и третье место в мире после США по импорту $(10,3 \%)^{1}$.

В 2017 г. товарооборот между ЕС и Китаем по своему объёму уступал лишь объёму торговли между ЕС и США. С 2001 по 2017 г. импорт ЕС из Китая увеличился с 88,7 млрд. евро до 402,4 млрд евро, а экспорт за тот же период вырос с 30,2 млрд евро до 195,3 млрд евро.

Торговля между ЕС и Китаем в 2017 г., млрд евро

\begin{tabular}{|l|c|c|c|c|c|c|c|c|c|}
\hline & Экспорт & $\begin{array}{c}\text { Доля в } \\
\text { экспорте } \\
\text { ЕС в } \\
\text { КНР }\end{array}$ & Импорт & $\begin{array}{c}\text { Доля в } \\
\text { импорте } \\
\text { ЕС из } \\
\text { КНР }\end{array}$ & Баланс & \multicolumn{2}{|c|}{$\begin{array}{c}\text { Доля } \\
\text { в импорте }\end{array}$} & \multicolumn{2}{|c|}{$\begin{array}{c}\text { Доля } \\
\text { в экспорте }\end{array}$} \\
\hline & $\% \%$ & & $\% \%$ & & Китая & ЕС & Китая & ЕС \\
\hline Германия & 86,5 & 44,3 & 102,0 & 25,3 & $-15,4$ & 5,3 & 9,8 & 7,2 & 6,7 \\
\hline Великобритания & 18,9 & 9,7 & 53,0 & 13,2 & $-34,1$ & 1,2 & 9,3 & 1,2 & 4,8 \\
\hline Франция & 18,8 & 9,6 & 49,0 & 12,2 & $-30,2$ & 1,4 & 9,0 & 1,4 & 4,1 \\
\hline Италия & 13,5 & 6,9 & 28,3 & 7,0 & $-14,9$ & 1,1 & 7,1 & 1,1 & 3,0 \\
\hline ЕС-4 & 137,7 & 70,5 & 232,3 & 57,7 & $-94,6$ & 9,0 & 35,2 & 10,9 & 18,6 \\
\hline ЕС-28 & 195,3 & 100 & 402,4 & 100 & $-207,1$ & 13,3 & 8,1 & 16,4 & 3,9 \\
\hline
\end{tabular}

Источник: подсчитано по UN COMTRADE.

В экспорте ЕС в Китай, составившем в 2017 г. 195,3 млрд евро, 36 млрд (18,4\%) пришлось на турбины, насосы и разного рода промышленное оборудование, 34,4 млрд $(17,6 \%)$ - на автомобили, 19,7 млрд $(10,1 \%)$ - на офисное и телекоммуникационное оборудование, включая 4,3 млрд на интегральные схемы, 12,7 млрд (6,5\%) - на оптику, 10,3 млрд (5,3\%) - на авиатехнику.

В 2017 г. в импорте ЕС из Китая, составившем 402,4 млрд евро, 110 млрд (27,3\%) пришлось на электрооборудование, включая 40,3 млрд на телефоны, 81,1 млрд (20,1\%) пришлось на продукцию машиностроения, включая 38,8 млрд на компьютерную технику, 46,1 млрд евро $(11,5 \%)$ - на одежду и обувь, 16,8 млрд евро $(4,1 \%)$ - на игрушки, 18,4 млрд евро $(4,6 \%)$ - на мебель и постельные принадлежности ${ }^{2}$.

10,5\% импорта, на Японию - соответственно 3,7\% и 3,2\%, на страны АСЕАН - 7,3\% и $4,9 \%$, страны Залива - 2,4\% и 5,3\%. Данные без учёта внутрисоюзной торговли даны по EU Trade G-2 09/11/2018, с учётом внутрисоюзной торговли по UN COMTRADE.

${ }^{1}$ Bce данные по торговле рассчитаны по статистике OOH (COMTRADE), за исключением специально оговорённых данных.

2 В 2017 г. весь объём экспорта КНР составил 2003,5 млрд евро, из которых 16,7\% пришлось на офисное электрооборудование, 9,7\% - на мобильные телефоны, 16,9\% - на промышленное оборудование, 8,5\% - на одежду и обувь, 3,9\% - на постельные принадлежности, 3,1\% - на оптику, 3,0\% - на автомобили, 1,9\% - на торговлю стальным прокатом. За последние пятнадцать лет главным изменением китайского экспорта стал переход от доминирования текстильных товаров, одежды, обуви, игрушек и прочего ширпотреба, к экспорту товаров с высокой добавленной стоимостью. В импорте Китая, составившего в 2017 г. 1632,1 млрд евро на офисное эл. оборуд. пришлось 10,7\%, на интегральные схемы Современная Европа, 2018, №6 
В 2017 г. отрицательный баланс торговли ЕС с Китаем достиг 207 млрд евро, что остаётся важнейшей, хотя и не единственной, проблемой двусторонней торговли. Брюссель считает, что китайские компании и прежде всего государственные фирмы прибегают к несправедливой конкуренции как на собственном рынке, так и в Европе. Со своей стороны Китай обвиняет ЕС в применении различного рода антидемпинговых пошлин. Обе стороны с переменным успехом подают жалобы в ВТО.

Торговля услугами значительно отстаёт от торговли товарами. В 2017 г. импорт услуг в ЕС в Китай составил 27,8 млрд евро, а экспорт - 44,7 млрд евро, что составило лишь восьмую часть от их объёма торговли. Несмотря на то что в период между 2010 и 2015 г. китайская торговля услугами росла на 25\% в год, они сохраняют отрицательное сальдо в торговле услугами с ЕС, составившее 16,9 млрд евро.

Среди стран ЕС главным торговым партнёром Китая является Германия, на которую в 2017 г. пришлось 44,3\% экспорта ЕС в Китай и 25,3\% импорта. Для Германии Китай, на которую пришлось 6,7\% экспорта, является третьим по значению рынком после США и Франции и первым среди импортёров $(9,8 \%$ немецкого импорта). Для Китая Германия, на которую пришлось 5,3\% импорта, является пятым по значению экспортёром после Республики Кореи, Японии, Тайваня и США, а среди покупателей китайских товаров Германия находится лишь на шестом месте после США, Гонконга, Японии, Республики Кореи и Вьетнама - 3,1\% от объёма китайского экспорта. Важность Германии для Китая определяется тем, что та является важнейшим экспортёром автомобилей в Китай, опережая таких крупнейших в мире автопроизводителей, как Япония, США, Великобритания и Республика Корея. В 2017 г. экспорт немецких автомобилей составил 27,4\% от объёма китайского автоимпорта ${ }^{1}$ На Германию, Францию, Великобританию и Италию в 2017 г. пришлось 70,5\% экспорта ЕС в Китай и 57,7\% импорта, на 16 стран Центральной и Восточной Европы пришлось 5,9\% экспорта и 18,1\% импорта.

\section{Борьба за расширение рынков инвестиций}

Несмотря на огромные объёмы торговых отношений и сопоставимость экономических потенциалов ЕС, США и КНР, инвестиционные отношения между ЕС и Китаем развиваются не слишком высокими темпами и значительно отстают от объёмов инвестиций между ЕС и США. В 2017 г. накопленные инвестиции ЕС в Китае составили 177,7 млрд евро, а китайские ПИИ в ЕС - 46,1 млрд евро ${ }^{2}$, тогда как европейские инвестиции в США достигли 2,6 трлн евро, а американские в ЕС $-2,4$ трлн ${ }^{3}$.

До середины десятых годов XXI века интерес инвесторов к Китаю определялся в первую очередь дешёвой рабочей силой и отсутствием серьёзного внимания вла-

- 14,2\%, на нефть - 8,9\%, на газ - 1,8\%, на промышленное оборудование - 9,2\%, на руды $6,8 \%$, на оптику $-5,3 \%$, на автомобили $-4,3 \%$.

${ }^{1}$ На Японию пришлось 20,8\%, на США - 19,1\%, на Великобританию - 9,4\%, на Корею $3,6 \%$. Экспорт российского автопрома в Китай оказался менее $0,1 \%$ от объёма китайского импорта автомобилей. Мы продали в Китай 734 легковых автомобиля, тогда как Германия свыше одного миллиона.

${ }^{2}$ European Comission, Directorat-General for Trade (DGN) 06/11/2018 (ec.europa.eu)

${ }^{3}$ Инвестиционные потоки между США и КНР тоже значительно превышают объём инвестиций между ЕС и КНР. Объём инвестиций США в Китае с 1990 по конец 2017 г. составил 256,5 млрд долл., а китайские инвестиции в Соединённых Штатах за тот же период достигли 139, 8 млрд долларов. [U.S. Bureau of Economic Analysis, July 30, 2018].

Современная Европа, 2018, №6 
стей к охране окружающей среды. С ростом китайской экономики привлекательность китайского рынка стала определяться увеличением внутреннего спроса в Китае, а затем и развитием сферы услуг.

Китайские ПИИ в ЕС в 2017 г. сократились на 17\% по сравнению с предыдущим годом, однако Пекин продолжает активно вкладывать деньги в европейскую экономику. Китайские инвестиции в страны ЕС выросли с 700 млн евро в 2008 г. до 30 млрд в 2017 г. В 2017 г. крупнейшим получателем китайских инвестиций в Европе стала Швейцария, после того как китайская химическая компания ChemChina купила летом 2017 г. за 38 млрд евро швейцарскую сельскохозяйственную компанию Syngenta.

В ЕС, с одной стороны, китайские инвестиции рассматривают как фактор развития экономики союза, но с другой - считается, что европейские инвесторы ЕС и Китай оказываются в Китае в неравном положении в сравнении с китайскими инвесторами в ЕС. Китайцы в ЕС пользуется теми же правами, что и любой инвестор, тогда как европейский бизнес сталкивается с формальными и неформальными ограничениями при попытках инвестировать в китайскую экономику, что также как во взаимной торговле связано с ролью государства в экономике Китая. В 2016 г. доля государственных компаний составляла в Китае 90,7\% в финансовой сфере, $89,9 \%$ - в здравоохранении, 61,9\% - во внутренней торговле [Garcia-Herrero, 2018]. Во многом именно на роли государства в экономике основывается оценка ОЭСР Китая как страны с наибольшей закрытостью инвестиционного рынка.

С января по май 2018 г. общий объём ПИИ в Китай составили 52,67 млрд долл., из которых на трёх крупнейших европейских инвесторов в экономику Китая пришлось 2,2 млрд долларов, или 4,2\% от объёма вложений. Главными инвесторами в экономику Китая традиционно остаются китайские компании "хуацяо" из Гонконга, на который пришлось $71,3 \%$ инвестиций, Сингапура $(5,3 \%)$ и Тайваня $(4,2 \%)$ [Ministry of Commerce, PRC, 2018].

Главной мотивацией китайских инвестиций в ЕС остаётся доступ к рынкам и технологиям, для Европы капиталовложения в Китае также стимулируются доступом к потребительскому рынку и к сфере услуг. Одной из проблем для европейских инвесторов в Китае остаётся привилегированная роль китайских государственных компаний на внутреннем рынке.

На 16-м саммите ЕС - КНР в ноябре 2013 г. было принято решение начать переговоры о заключении инвестиционного соглашения призванного заменить двусторонние соглашения. Было принято решение за основу обсуждения принять инвестиционную главу проекта TTIP. В качестве цели рассматривалось прежде всего стремление сторон облегчить взаимный допуск на рынки друг друга и обеспечение гарантированной защиты инвестиций. Однако решение администрации Д.Трампа фактически заморозить переговоры по этому соглашению серьёзно затруднили обсуждение нового инвестиционного соглашения. В июле 2018 г. в Брюсселе прошёл 18-й раунд переговоров по заключению инвестиционного соглашения, однако далее согласования ряда частных вопросов будущего договора стороны не продвинулось. Следующее заседание намечено на конец октября в Пекине ${ }^{1}$.

${ }^{1}$ Report of the $18^{\text {th }}$ round of negotiations fomr the EU-China Investment Agreement (trade ec.europe.eu. Brussels, 18 July 2018).

Современная Европа, 2018, №6 
Несмотря на то что летом 2017 г. глава КНР Си Цзиньпин призвал “относиться к иностранным компаниям в Китае как “к равным перед законом”, а Госсовет КНР в появившемся в августе того же года “гарантировал отмену дискриминации иностранных компаний в сфере налогообложения, вывода прибыли, получении виз"1, по мнению западных аналитиков эти правила далеко не всегда соблюдается. В ходе 20-го саммита ЕС - КНР было принято решение о создании Фонда взаимного инвестирования ЕС и КНР, и о продолжении переговоров о заключении инвестиционного соглашения, обеспечивающего "открытое, предсказуемое, честное и прозрачное ведение бизнеса при взаимном инвестировании”.

Однако несмотря на оптимистические оценки Брюсселя и Пекина, перспективы заключения нового договора, существующие политические ограничения вряд ли позволят в обозримом будущем успешно завершить эти переговоры. Китай, имея опыт европейской колонизации, сохраняет недоверие к западным инвестициям. В ЕС существует проблема acquis communautaire - вопрос разделения компетенций между Брюсселем и государствами - членами ЕС, большинство из которых имеют собственные инвестиционные соглашения с Китаем и ведут с ним двусторонние переговоры по вопросам торговли и инвестиций. Компромиссы с обеих сторон возможны, но потребуют долгих и трудных переговоров.

\section{Туризм и студенческий обмен}

Одним из заметных направлений развития сотрудничества между ЕС и Китаем в XXI веке стали туризм и обмен студентами. На 18-м саммите ЕС - Китай было принято решение провозгласить 2018 г. Годом туризма. В 2017 г. Китай посетило около 6 млн жителей Европы, что составило более 30\% иностранных туристов, приехавших в страну. Быстрыми темпами росла и численность китайцев, посещавших Европу. С 2,79 млн человек в 2015 г. их число увеличилось до 5,13 млн в 2016 г. Учитывая, что каждый китаец тратит в ходе пребывания в Европе 2200 евро, то их суммарные расходы составили около $0,3 \%$ ВНП стран ЕС, что позволило открыть примерно 1,1 млн рабочих мест. Больше всего в Китай приезжает немцев, англичан, французов и итальянцев. По прогнозам в 2025 г. расходы китайских туристов в Европе обеспечат почти один процент ВВП стран ЕС.

Между ЕС и Китаем заключено свыше 80 двусторонних соглашений в сфере образования. В Европе получают образование более 300 тыс. китайских студентов, или четверть всех студентов-иностранцев. По оценкам, каждый китайский студент тратит в стране пребывания около 30 тыс. долл. США, что составило 0,25\% ВВП стран ЕС в 2015 г. и создало около миллиона рабочих мест в ЕС. В 2015 г. в Китае обучалось 45 тыс. студентов из стран ЕС, 3 тысячи из которых получали стипендию от правительства КНР. В китайских университетах представлены все 24 официальных языка ЕC, а 620 тысяч европейцев изучают китайский язык в 160 Институтах Конфуция в Европе. Так как более трети китайских студентов обучается в Великобритании, ожидается, что после брекзита сотрудничество между ЕС и Китаем в области образования сократится. Однако уже сегодня идут переговоры между Брюсселем и Пекином о расширении сотрудничества в рамках EC-27 [Garcia- Herero, 2017].

\footnotetext{
${ }^{1}$ Ministry of Commerce, PRC

(http://www.mofcom.gov.cn/article/ae/ai/201708/20170802627851.html)

Современная Европа, 2018, №6
} 


\section{“16+1" и “Один Пояс-Один путь”}

Укрепляя свои позиции в Европе, Китай опирается не только на отношения с руководством ЕС и двусторонние связи с государствами Европейского Союза, но и на два глобальных проекта, в которые в той или иной форме оказались вовлечёнными практически все страны ЕС. Это программа “16+1” и “Один пояс - Один путь”.

Программа сотрудничества между Китаем и странами Центральной и Восточной Европы (ЦВЕ) была начата по инициативе Пекина в 2012 г. и получила неофициальное название " $16+1$ ” - 16 стран ЦВЕ ${ }^{1}$ и Китай. С первого саммита в Варшаве в 2012 г. до конца 2018 г. стороны провели ещё шесть подобных встреч. Последняя такая встреча была проведена в Софии в июле 2018 г. В своих отношениях с этими странами ЕС и “примкнувшими” к ним кандидатами на вступление Китай исходит из понимания их экономических и социальных проблем в рамках “двухскоростного” разделения Европы на старых и новых членов ЕС. В Пекине почувствовали существующий среди них естественный комплекс политической неполноценности, отправляя на все саммиты премьер министра КНР².

Если говорить о конкретных экономических результатах сотрудничества между странами ЦВЕ и Китаем, то с 2013 по 2017 г. экспорт Китая в эти страны вырос с 30,5 млрд евро до 43,6 млрд евро, а импорт Китая увеличился с 10,8 до 16,5 млрд евро. При этом в 2017 г., как и в 2013 г., свыше 70\% экспорта и импорта пришлось на Польшу, Чехию, Венгрию и Словакию. Все 16 стран этой группы имеют отрицательное сальдо в торговле с Китаем, которое за этот период выросло с 19,7 млрд евро до 27,2 млрд евро. Объём китайских инвестиций в регион по оценке премьер министра КНР Ли Кэцяня с 2013 г. составил около 10 млрд долл., предоставляемых в основном в виде займов, инвестиции стран ЦВЕ в Китай оцениваются в 1,4 млрд долларов. [Diplomat, 2018].

В Пекине хорошо понимают, что руководство ЕС рассматривает $16+1$ как попытку действовать в ЕС и в Европе в обход Брюсселя. В ходе саммита в Софии в июле 2018 г премьер министр КНР Ли Кэцян заверил Брюссель в том, что “в сотрудничестве “16+1" могут участвовать любые страны”, а “такая возможность для укрепления партнёрства особенно важна в условиях, когда во всём мире то и дело вводятся ограничительные меры" ${ }^{3}$. После саммита китайский премьер посетил Берлин, где подписал предварительное соглашение с компанией BASF о строительстве в провинции Гуандунь химического комплекса стоимостью в 10 млрд долл., собственником которого впервые за историю инвестиционных отношений между ЕС и

\footnotetext{
1 Это 11 стран ЕС - Болгария, Венгрия, Латвия, Литва, Польша, Румыния, Словакия, Словения, Хорватия, Чехия, Эстония и пять Балканских стран - Албания, Босния и Герцеговина, Македония, Сербия, Черногория.

${ }^{2}$ Интересно отметить, что Польша, считающая себя первой среди стран ЦВЕ, на последний саммит в Софию достаточно демонстративно отправила не премьер-министра, а вицепремьера Ярослава Говина, который заявил в Софии, что “польское правительство высоко ценит многомерность встреч в рамках саммитов “16+1", которые для многих стран предоставляют уникальную возможность для проведения диалога с Китаем на высшем уровне". (Kowalski Bartosz, What's Next for the China-CEE 16+1 Platform? (thediplomat.com, July 13, 2018).

3 Ли Кэцян.
} 
КНР станет иностранная компания, что явилось своего рода попыткой успокоить Германию относительно китайской активности в ЦВЕ.

Европейская политика Китая, включая отношения со странами ЦВЕ, тесно связана и с проектом “Один пояс - один путь”, выдвинутым председателем КНР Си Цзиньпином в 2013 г. в качестве китайской модели мирового развития. Он предусматривал строительство сухопутного и морского маршрутов между Азией и Европой и развитие экономической инфраструктуры вдоль транспортных артерий. Проект стал центром политики Китая начиная с 2015 г. и частью “13-й пятилетки”, начавшейся в 2016 г. Проект затрагивал интересы стран, где проживает более $60 \%$ населения земли, а стоимость его оценивалась в астрономическую сумму 21 трлн долларов ${ }^{1}$.

Европейская политика на фоне глобальных амбиций Китая и прихода в Белый дом Д. Трампа оказалась между сомнениями в незыблемости трансатлантического союза и призывами Китай строить новый мировой порядок вдоль Шёлкового пути. Оба фактора значительны и неопределённы. Никто не может прогнозировать ни будущее американской политики, ни судьбу грандиозного китайского проекта, peaлизация которого позволит Китаю контролировать не только торговые пути между Азией и Европой, но и лишить Америку единоличного лидерства в мире. Как писал журнал International Affairs, "Решение Трампа выйти из ТTР открыло перед Китаем возможность реализовать мечту сделать Китай снова великим”. В январе 2018 г. участники этого соглашения приняли решение сохранить союз без США, а Китай активизировал своё участие ведущихся с ноября 2012 г. переговорах о заключении Соглашения о всеобъемлющем экономическом партнёрстве (Regional Comprehensive Economic Partnership), в котором участвует Китай, страны ACEAH, Австралия, Новая Зеландия, Индия, Япония и Республика Корея. По сути, новое соглашение без участия США, Канады и трёх латиноамериканских стран, но при участии КНР в случае его реализации изменит баланс сил в Азии и в мире в пользу Китая.

Поскольку проект носил интеграционный и межконтинентальный характер, его реализация стала предметом широкого обсуждения в Европе. С одной стороны, руководство ЕС проявило серьёзный интерес к китайской инициативе, и видела в ней возможность расширения экономических связей между ЕС и Китаем. В 2015 г. наиболее активным сторонником участия в китайском проекте выступила Великобритания. В ходе визита в Великобританию в мае 2015 г. председатель Си Цзиньпин и тогдашний премьер министр Великобритании Дэвид Камерон провозгласили “золотой век отношений между Китаем и Великобританией”, одной из основ которого было сотрудничество в китайском проекте.

В то же время в Европе существует двойственное отношение к новому Шёлковому пути. С одной стороны, развитие глобальной торговли требует надёжных и, главное, быстрых путей доставки товаров. Создание инфраструктуры вдоль новых транспортных артерий потенциально создаёт множество рабочих мест и требует

${ }^{1}$ По своей сути, это было возрождением Шёлкового пути, который, с III в. до нашей эры связал Азию с Европой. Караванные тропы соединили Чаньанъ (Сиан) и Самарканд, откуда через Согдиану, Бактрию и Парфию можно было добраться до Малой Азии и Европы. Морским путём товарообмен шёл через гавани Вьетнама, Цейлона, Набатеи, Египта и Венеции. С другой стороны, Шёлковый путь в немалой степени способствовал развалу Римской империи. В Азии покупались предметы роскоши и прежде всего шёлк. Расплачивался Рим в основном серебром, что, несмотря на многочисленные запреты, сильно опустошало казну.

Современная Европа, 2018, №6 
инвестиций. Однако в Европе существуют опасения, что “один путь” может оказаться дорогой в одну сторону. Как говорилось в докладе 27 послов ЕС в Пекине ${ }^{1}$, китайский проект "противоречит повестке дня ЕС по либерализации торговли и подталкивает баланс сил в пользу субсидируемых Китаем компаний” [Saarela, 2018]. В ответ Си Цзиньпин заявил, что “проект Шёлковый путь не является заговором, как считают многие за рубежом, и Китай не собирается играть в геополитические игры в собственных интересах" проекту находятся в русле инвестиционных отношений между ЕС и Китаем. Пекин обвиняют в отсутствии прозрачности при государственных закупках и равных возможностей для всех инвесторов при создании транспортной инфраструктуры, в преференциях китайским государственным компаниям при торгах. Как отмечало исследование, проведённое по заказу Европарламента, "Китаю необходимо наполнить свои объявленные цели проекта BRI платформой обязывающей следованию рыночным правилам и международным нормам, что даст возможность всем получить выгоды и обеспечит ответственное экономическое поведение в третьих странах" [Saarela, 2018].

Определённые опасения вызывают и попытки Китая приобрести контроль над стратегически важными объектами в Европе. С одной стороны, ЕС заинтересован в привлечении китайских денег для реконструкции портов, а с другой - в силу того, что $70 \%$ внешнеторгового оборота ЕС проходит через десять европейских портов ${ }^{3}$, делает их стратегически важным для экономики Европы. В сентябре 2017 г. Юнкер предложил программу рассмотрения иностранного инвестирования, основанную на том, что “в случае если зарубежная компания собирается купить европейский порт, часть нашей энергетической инфраструктуры или компанию, работающую с оборонными технологиями, это можно сделать только на основе полной прозрачности сделки, тщательного анализа и обсуждения". В Брюсселе не без оснований считают, что политика Пекина в отношении участия EC в проекте BRI использует отход от принципа единства принятия решений в ЕС. В рамках отношений с государствами Центральной и Восточной Европы Китай активно продвигает разного рода инвестиционные проекты, выгодные для стран региона ${ }^{4}$, а в ответ, страны региона в ноябре 2017 г. на 6-м саммите 16+Китай в Будапеште признали участие в проекте BRI “приоритетным”. Подобный “сепаратизм” не может не раздражать руководство EC, относящееся к китайским инициативам более сдержанно. В мае 2017 г. в Пекине в форуме “Один пояс - Один путь" участвовали премьер министры шести из 28 стран ЕС 5 , однако отсутствовали представители Германии, Великобритании и Франции.

\footnotetext{
1 Доклад не подписал посол Венгрии в Пекине.

2 (global.handesblatt.com April 17, 2018).

${ }^{3}$ Роттердам, Бремерхафен, Гамбург, Антверпен, Филикстоу, Гавр, Валенсия, Альхесирас, Пирей, Джоя- Тауро.

${ }^{4}$ Сербия для строительства железной дороги получила от китайского Эксим Банка заем в 297,6 млн евро, Китай обещал Венгрии предоставить деньги для строительства железной дороги, а всего ПИИ Китая в страны региона оцениваются в 14,4 млрд долл. США [Saarela, 2018: 9].

5 Участвовали премьер министры Испании, Италии, Греции, Польши, Чехии и Венгрии.
}

Современная Европа, 2018, №6 


\section{Заключение}

Говоря о перспективах отношений между ЕС и Китаем, необходимо отметить, что они лишены недостатков и противоречий, свойственных другим виртуальным парам мирового бомонда. В отличие от США Брюссель не перессорился с Китаем, а в его отношениях с Пекином, если не считать давно ставшими ритуальными дебатов по вопросам соблюдения прав человека в Китае и визитов Далай Ламы в Европу, нет идеологических конфликтов. Их экономики высокоразвиты и вполне сопоставимы, что в целом обеспечивает баланс интересов, а географическая отдалённость лишает их военно-стратегических противоречий. Это не значит, что между ЕС и Китаем не сохраняются серьёзные экономические конфликты, неизбежные при столь огромных объёмах торговых и инвестиционных связях, однако они не лишают обе стороны надежд на расширение отношений в будущем.

Согласно проведённому в Китае исследованию, в случае если ЕС и Китай в ближайшее десятилетие смогут успешно провести структурные реформы, сохранив для КНР годовой рост ВВП в $6 \%$, а для ЕС свыше 1,7\%, то объём китайского экспорта в ЕС в 2025 г. достигнет 404 млрд евро (455 млрд долл.), а импорт составит 277 млрд евро (312 млрд долл.). В случае если рост ВВП не достигнет намеченных параметров, китайский экспорт в ЕС составит 393 млрд евро (442 млрд долл.), а импорт 271 млрд евро (305 млрд долл) [Garcia].

Политика президента Трампа ведёт к конфронтации между тремя лидерами экономического мира. Однако конфликты между Европой и США - это повторение пройдённого: достаточно вспомнить выход де Голля из военной структуры НАТО в 1966 г., отказ Германии и Франции поддержать войну США против Ирака в 2003 г. или наступление Трампа на торговые отношения с ЕС. Европа и США могут ссориться, но и умеют мириться, тем более что сегодня они вновь рассматривают Россию как врага. Что касается конфликта Запада с Китаем, он, к счастью для обеих сторон, лишён идеологической основы и всерьёз не рассматривается ни в Брюсселе, ни в Вашингтоне в качестве главной угрозы безопасности. По своим масштабам и потенциальной опасности для Запада действия Китая в Южно-Китайском море несопоставимы с нынешним противостоянием между ним и Россией в Европе.

Расширение экономических связей ЕС с Китаем и с Азией ставит перед Россией вопрос о перспективах наших экономических и политических отношений с ЕС и Китаем, крупнейшими российскими торговыми партнёрами. Импорт России из ЕС с 2013 по 2017 г. сократился с 101 млрд евро до 71,9 млрд, а экспорт - с 181,6 млрд евро до 115,2 млрд евро. За эти же годы импорт России из Китая вырос с 40 млрд евро до 42,8 млрд, а экспорт увеличился с 26,8 млрд до 33,2 млрд евро. Сегодня Китай является одной из стран, которая не присоединилась к политике фактической изоляции России, однако, к сожалению, статистика показывает несопоставимость объёмов торговли России с ЕС и Китаем, не говоря уже о торговле между ними. России предстоит ещё многое сделать, чтобы увеличить торговый оборот с Китаем, но делать это в ущерб нашей торговле с Европой опасно для нашего развития. Многие высокотехнологичные товары, которые мы закупаем в ЕС, покупать в Китае невозможно в силу их отсутствия там.

Китай - наш близкий сосед, и отношения с ним должны всегда оставаться приоритетом нашей политики. Однако союз России с Китаем с очевидной антизапад- 
ной направленностью невозможен по нескольким причинам. Во-первых, руководство Китая исходит из того, что будущее их страны связано с торговлей, без которой развитие и даже стабильность экономики невозможны. Россия таким рынком ни сегодня, ни в обозримом будущем быть не может ${ }^{1}$. Конкурентная борьба Китая за рынки и политическое влияние с США и ЕС будет существовать всегда, она может принимать самые ожесточённые формы, но они никогда не допустят разрушения торговых связей между ними, на которые приходится больше половины мировой торговли ${ }^{2}$.

Во-вторых, сегодня развитие Китая связано с современными технологиями и зависит от американского и европейского рынка. Технологическая изоляция от передовых стран гибельна для конкурентоспособности любого игрока на арене глобальной политики.

В-третьих, глобальная напряжённость неизбежно входит в противоречие с поддержанием темпов роста экономики Китая, а союз между Москвой и Пекином с явным антизападным вектором неизбежно приведёт к гонке вооружений и экономической стагнации.

В своих отношениях с ЕС и США Китай сумел, не отказываясь от своих идеологических принципов и проводя собственную национальную политику, создать прочные основы отношений с Западом. Имея серьёзные противоречия с США по вопросу о Тайване, Китай поддерживает отношения с территорией, которую он справедливо считает частью Китая, так как это устраивает все три стороны конфликта. Отказ от силового решения проблемы во многом дал возможность Китаю за короткие сроки создать мощную экономику и стать одной из великих держав мира и крупнейшим торговым партнёром ЕС и США.

Сегодня отношения между Россией и ЕС и с Западом в целом не просто плохие - они катастрофически опасны. Мы идём по пути дальнейшей экономической и политической изоляции от ведущих стран мира. С 2007 г. после мюнхенской речи В. Путина, которая для нынешнего этапа холодной войны стала эквивалентом фйултонской речи У. Черчилля, мы всё ближе подходим к черте, когда простая человеческая ошибка может стать причиной ядерной катастрофы. Хотя президент справедливо отметил в Мюнхене, что “односторонние нелегитимные часто действия не решили ни одной проблемы”, дальнейшие действия России опирались на другой тезис этой речи: "Россия - страна с более чем тысячелетней историей, и практически всегда она пользовалась привилегией проводить независимую внешнюю политику"3. Наши действия в 2014 г. не учитывали ни интересы Украины, ни интересы подавляющего большинства мирового сообщества ${ }^{4}$. К сожалению, мы не хотим понять это и упорно отказываемся соотносить наши интересы с нашими реальными возможностями, а главное - с будущим нашей страны.

\footnotetext{
${ }^{1}$ В 2017 г. Россия импортировала товаров меньше Вьетнама и Турции, а её экспорт уступал Бельгии или Сингапуру.

${ }^{2}$ На Китай, ЕС и США в 2017 г. пришлось 55,4\% мирового импорта и 54,1\% экспорта.

${ }^{3}$ Kremlin.ru/events/president/transcripts/24034 (10/02/2007)

${ }^{4}$ Крым официально был признан частью России Афганистаном, Венесуэлой, КНДР, Никарагуа, Сирией и Арменией.
} 
Список литературы

Бажан А.И. (2018) Шёлковый путь: последствия для ЕАЭС и ЕС, Аналитическая записка №47, ИЕ РАН.

Носов М.Г. (2010) Европа и Азия: политика, экономика, безопасность, М., Русский сувенир.

Носов М.Г. (2015) ЕС - Китай в "Европейский союз в поиске глобальной роли: политика, экономика, безопасность” (Под общей редакцией Громыко Ал.А. и Носова М.Г.), М., Весь мир, стр. 268287.

Garcia-Herrero Alicia, Kwok K.C., et.al. (2017) EU-China Economic Relations to 2025: Building a Common Future A Joint Report by Bruegel, Chatham House, China Center for International Economic Exchanges and The Chinese University of Hong Kong, L., The Royal Institute of International Affairs, September.

Saarela Anna. (2018) A New Era in EU-China relations: more wide-ranging strategic cooperation?, European Parliament.

\section{References}

Bazhan A.I. (2018) Shelkovii put: posledstvia dlya EAES I EC, Analiticheskaya zapiska № 47, IE RAN.

Bradley Michael, AFP February 4, 2016 Biggest ever trade deal signed as US seek to counter China

Pew Research Center, 07/14/2018 http://www.pewglobal.org/2014/07/14/chapter-3-balance-of-power-us-vs-china/ (Дата обращения 11/8/2018)

Garcia-Herrero Alicia, Kwok K.C., et.al. (2017) EU-China Economic Relations to 2025: Building a Common Future A Joint Report by Bruegel, Chatham House, China Center for International Economic Exchanges and The Chinese University of Hong Kong, L., The Royal Institute of International Affairs, September.

Global Times 5/31/2017 www.globaltimes.cn/content/1049431.shtml

European External Action Service (eeas.org)

EU Trade G-2 (ec.europa.eu)

Kremlin.ru/events/president/transcripts/24034 (10/02/2007) (Дата обращения 28/9/2018)

Mahler Richard, (2016) The Elusive EU-China Strategic Partnership, Internationa Affairs, July 2016, p.

962 AFP February 4, 2016 concillium.europa.eu (Дата обращения 18/5/2018)

Ministry of Commerce, PRC (mofcom.gov.cn) (Дата обращения 15/11/2018)

Nosov M.G. (2010) Evropa I Azia: politica, ekonomika, bezopasnost, M, Ruskii Suvenir.

Nosov M.G. (2015) ES-Kitaii v "Evropeiskii souz v poiske globalnoii roli: politica, economika, bezopasnost" (pod obshei redakziei Gromyko Al.A., I Nosova M.G.) M., Ves Mir, str. 268-287

Saarela Anna. (2018) A New Era in EU-China relations: more wide-ranging strategic cooperation?, European Parliament.

The Diplomat (thediplomat.com 13/07/2018) (Дата обращения 17/10/2018)

UN COMTRADE DATABASE (Дата обращения 18/1/2018)

White House (www.whitehouse.gov) November 9, 2017 (Дата обращения 14/5/2018)

\section{EU and China: trade or strategy}

Author: Nosov M., Corresponding Member of the Russian Academy of Sciences, Member of the Executive Board of the Institute of Europe. Address: 11-3, Mokhovaya str., Moscow, Russia, 125009. E-mail: mikhailnosov@mail.ru

Abstract. In 2018, the EU and China celebrated the 15th anniversary of the proclamation of a comprehensive strategic partnership. In 2003, when they decided to increase the level of bilateral relations, both did not claim a global role. China pursued a policy of refusal to join any alliances. The EU was content with the role of an economic giant and did not seriously discuss the issue of creating its own armed forces. At the beginning of the 21 st century, EU leaders tried, and often successfully, to teach the Chinese to trade in the open market. Today it is a dialogue of two equal partners. Beijing even surpasses Brussels in promoting alternative world development models. Today, in terms of trade volumes, the EU and China are respectively the first and second in the world, and the volume of trade between them is second only to the volume of trade between the EU and the United States. Today in the EU they speak increasingly about European army, whereas the Chinese think about a "Great Chinese dream". The article does not give a clear-cut answer about proximity of such goals, but tries to outline the framework of their possible implementation.

Key words: EU, China, trade, investment, security.

DOI: http://dx.doi.org/10.15211/soveurope620180517

Современная Европа, 2018, №6 